\title{
An Innovative Stability Indicating RP-HPLC Assay Method for the Determination of Caroverine in Pharmaceutical Bulk and Tablets
}

\section{Raza $A^{*}$ and Ansari TM}

Division of Analytical Chemistry, Institute of Chemical Sciences, Bahauddin Zakariya University, Multan, Pakistan

"Corresponding author: Raza A, Division of Analytical Chemistry, Institute of Chemical Sciences, Bahauddin Zakariya University, Multan 60800, Pakistan, Tel: 00923009639949; Fax: 92-61-6524270; E-mail: asadbzu@gmail.com

Received date: March 05, 2017; Accepted date: March 16, 2017; Published date: March 20, 2017

Copyright: (c) 2017 Raza A, et al. This is an open-access article distributed under the terms of the Creative Commons Attribution License, which permits unrestricted use, distribution, and reproduction in any medium, provided the original author and source are credited.

\begin{abstract}
An innovative, quick and easy reversed phase high performance liquid chromatographic method is elaborated and authenticated for the quantitative determination of caroverine in pharmaceutical bulk material and tablets. Shimpack CLC-ODC $\left(\mathrm{C}_{18}\right)$ column was used. The mobile phase acetonitrile and buffer solution $(30: 70) \mathrm{pH} 4.9$ is transmitted at a flow rate of $1 \mathrm{~mL} / \mathrm{min}$. The eluent was observed using UV detector at $225 \mathrm{~nm}$. The recent developed RP-HPLC method is specific, accurate, precise and linear $\left(R^{2}>0.998\right)$ within the range of $2-150 \mu \mathrm{g} / \mathrm{mL}$ concentration. The limit of detection and quantification is $0.068 \mu \mathrm{g} / \mathrm{mL}$ and $0.201 \mu \mathrm{g} / \mathrm{mL}$ respectively. The newly proposed method is applied to determine caroverine in pharmaceutical tablet formulations. The developed method is optimized using samples generated by forced degradation studies. Results of analysis are validated statistically. The method was selective, precise, accurate and can be used for routine analysis of caroverine in quality control laboratories of pharmaceutical industries.
\end{abstract}

Keywords: Caroverine; High Performance Liquid Chromatography (HPLC); Method validation; Stability indicating; Pharmaceutical formulations

\section{Introduction}

A counterfeit medication or a counterfeit drug is a medication or pharmaceutical product which is produced and sold with the intent to deceptively represent its origin, authenticity or effectiveness. A counterfeit drug may contain inappropriate quantities of active ingredients, or none, may be improperly processed within the body (e.g., absorption by the body), may contain ingredients that are not on the label [1]. The concern about the quality of drugs marketed increases every year not only in commercial terms, but also legal and ethical aspects, since the health of patients depends on the quality and effectiveness of these drugs. For this purpose different regulatory authorities around the world are demanding specific and validated analytical methods for the registration of new drugs to ensure their quality. So there is a great interest in developing rapid and efficient analytical methods that provide precise and accurate parameters for the quantitative analysis of drugs in pharmaceutical raw and dosage forms.

Caroverine 1-(2-diethylaminoethyl)-3-(p-methoxybenzyl)-1,2dihydro-2-quinoxalin-2-on-hydrochloride is chemically derived from isoquinoline, the basic structure of papaverin. It is clinically available in some countries as a spasmolytic drug based on its unspecific $\mathrm{Ca}^{2+}$ channel blocking activity for more than 40 years. Caroverine is a drug used as a spasmolytic and otoneuroprotective (inner ear protective) agent in some countries. It acts as an N-type calcium channel blocker, competitive AMPA (a-amino-3-hydroxy-5-methyl-4isoxazolepropionic acid receptor) receptor antagonist, and noncompetitive NMDA (N-methyl-D-aspartate receptor) receptor antagonist [2]. It also has potent antioxidant effects [3]. In Pakistan, caroverine is marketed as Saprina tablets $20 \mathrm{mg}$ (Biopharma, Multan, Pakistan) for oral smooth muscle spasms.

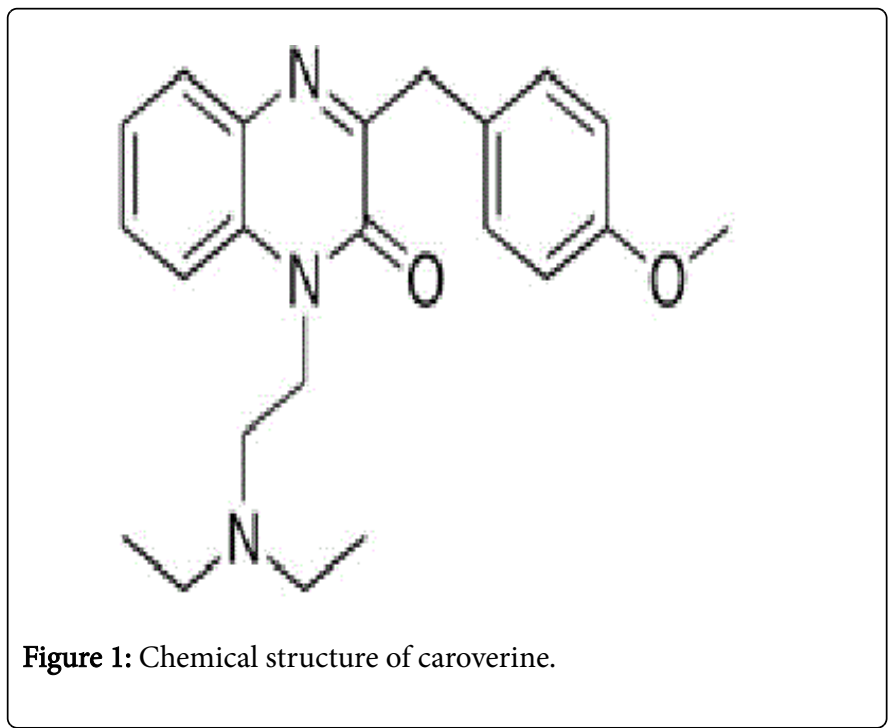

The entire inspection of literature for caroverine determination disclosed that not a single analytical method is available. Up to our knowledge the assay of caroverine in pure and dosage forms is not official in any pharmacopoeia and therefore, requires much more investigation. However we are very first time reporting here a best and latest analytical method for the determination of caroverine using a sensitive analytical techniques like RP-HPLC.

\section{Aim of the study}

Due to non-availability of any analytical procedure for the determination of caroverine in pharmaceutical raw and dosage forms a 
very intensive care has been taken to develop this method. The purpose of this study is to develop a validated analytical method by RP-HPLC to quantify caroverine in pharmaceutical raw and dosage forms. The reported method was validated according to International Conference on Harmonization (ICH) guidelines [4]. The stability indicating property of the proposed method was also evaluated.

\section{Experimental}

\section{Material and reagents}

Standard bulk drug sample and tablets of caroverine were supplied by BioFine Pharmaceuticals (Pvt.) Ltd. Multan, Pakistan. HPLC grade acetonitrile and methanol were obtained from Merck, Germany.

\section{Instrumentation}

HPLC system equipped with Shimadzu LC-20AT Pump, SPD-20A Shimadzu UV visible detectors connected by CBM-20A communication Bus Module Shimadzu to Intel Pentium 4 machine with Shimadzu software LC solutions 1.22 SPI and Rheodyne manual injector fitted with a $20 \mu \mathrm{L}$ loop. Separation was achieved on Shimpack CLC-ODC $\mathrm{C}_{18}(250 \times 4.6 \mathrm{~mm}, 5 \mu \mathrm{m})$ column. The chromatographic analysis was integrated using a mobile phase, which was acetonitrile and buffer solution $(30: 70, \mathrm{v} / \mathrm{v}) \mathrm{pH}$ 4.9. The mobile phase was sonicated by (LC-30 H, Elma, Germany) and filtered through 0.45micron membrane filter, calibrated Pyrex glassware was used for the solution and mobile phase preparation.

\section{Preparation of buffer and mobile phase}

Buffer solution was prepared by dissolving $1.2 \mathrm{~g}$ of ammonium dihydrogen phosphate (Merck) in $1 \mathrm{~L}$ of deionized water. The $\mathrm{pH}$ of this solution was 4.2 without any adjustment. Then we prepared acetonitrile and buffer solution in ratio of $30: 70$ whose $\mathrm{pH}$ was 4.9. This solution was used as mobile phase and diluents during the whole study.

\section{Chromatographic conditions}

The chromatographic analysis was performed at ambient temperature $\left(25^{\circ} \mathrm{C}\right)$ with isocratic elution. The mobile phase consisted of acetonitrile and buffer solution (30:70, v/v) $\mathrm{pH}$ 4.9. The pump was set at a flow rate of $1.0 \mathrm{~mL} / \mathrm{min}$, sample volume of $10 \mu \mathrm{l}$ was injected in triplicate into the HPLC column and elute was monitored at $\lambda_{\max }$ of $225 \mathrm{~nm}$.

\section{System suitability}

$20 \mu \mathrm{g} / \mathrm{mL}$ concentration of caroverine standard was prepared and injected into the chromatographic system as three replicates. The tailing factor for the caroverine peak from the first injection of the standard preparation should be less than 2.0 , and the column efficiency determined from caroverine peak from the first injection of the standard preparation should not be less than 1500 theoretical plates. The relative standard deviation for the mean area calculated for caroverine peak from the three replicate injections of standard preparation should be less than $2.0 \%$.

\section{Preparation of standard solution}

An accurate weight of $10 \mathrm{mg}$ of the pure drug was dissolved in 100 $\mathrm{mL}$ mobile phase to produce a concentration of $100 \mu \mathrm{g} / \mathrm{mL}$ of caroverine. This solution was used for preparation of working solutions which were prepared by diluting the stock solutions with the same solvent to contain $2-150 \mu \mathrm{g} / \mathrm{mL}$ for caroverine then filtered with 0.45 micron membrane filter. This solution was ready to inject.

\section{Construction of calibration curve}

From the standard stock solution, a series of solutions were prepared at concentration levels ranging from $2-150 \mu \mathrm{g} / \mathrm{mL}$ of standard concentration. The peak area responses of solutions at all levels in duplicate were measured. The peak response verses concentration data was treated by linear regression analysis and the linearity of response for caroverine was determined by calculating correlation coefficient (acceptance criterion: correlation coefficient shall not be less than 0.999 .

\section{Stability of analytical solution}

Standard and sample solutions of caroverine tablets were prepared and kept at $25^{\circ} \mathrm{C}$. Both the solutions were analyzed initially and at different time intervals. Cumulative $\%$ RSD of area counts for the standard solution and assay (\% claim) for the sample solution was calculated. In standard solution, cumulative\% RSD of area counts up to $10 \mathrm{~min}$ at $25^{\circ} \mathrm{C}$ was calculated. In sample solution, cumulative $\%$ RSD of assay (\%claim) up to $10 \mathrm{~min}$ at $25^{\circ} \mathrm{C}$ was calculated (acceptance criteria: cumulative\% RSD shall not be more than 2.0).

\section{Forced degradation}

Caroverine was intentionally subjected to stress conditions to determine the stability indicating nature of the method. The drug was exposed to light (in a stability chamber at about $24 \mathrm{~h}$ at $200 \mathrm{~W}$ ), heat $\left(105^{\circ} \mathrm{C}\right.$ for $\left.24 \mathrm{~h}\right)$, acid $\left(5.0 \mathrm{~N} \mathrm{HCl} 5 \mathrm{~mL} / 70^{\circ} \mathrm{C} / 30 \mathrm{~min}\right)$, alkali $(0.1 \mathrm{~N}$ $\left.\mathrm{NaOH} 5 \mathrm{~mL} / 70^{\circ} \mathrm{C} / 30 \mathrm{~min}\right)$, oxidation $\left(3.0 \% \mathrm{H}_{2} \mathrm{O}_{2} 5 \mathrm{~mL} / 70^{\circ} \mathrm{C} / 30 \mathrm{~min}\right)$ and humidity ( $95 \% \mathrm{RH}$ for $48 \mathrm{~h}$ ) to evaluate the ability of the method to separate caroverine from its degradation products. Peak purity was determined using PDA detector.

\section{Results and Discussion}

\section{Selection of detection wavelength}

$10 \mu \mathrm{g} / \mathrm{mL}$ solution of caroverine standard prepared in mobile phase was scanned at double beam UV/Visible spectrophotometer Hitachi 1800 from 180 to $800 \mathrm{~nm}$ against and reagent blank. The maximum wavelength was found to ne $225 \mathrm{~nm}$ that was selected for further optimization (Figure 1). 


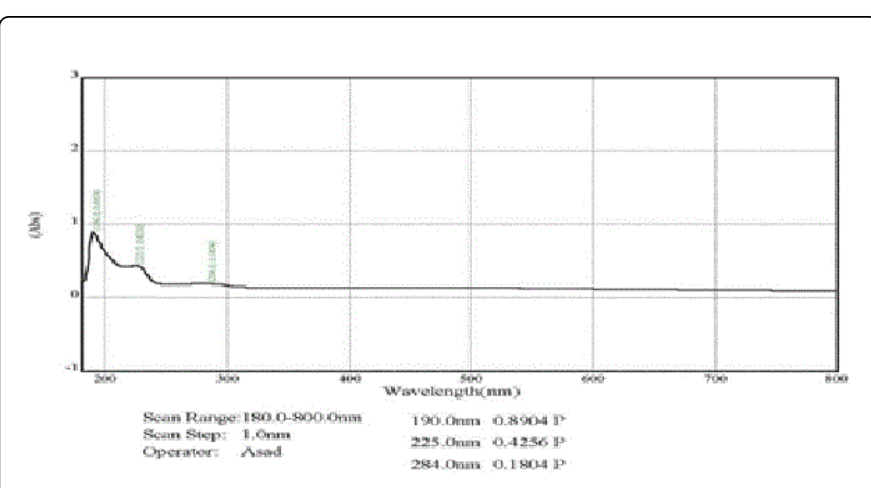

Figure 2: Wavelength maximum of caroverine in mobile phase solvent.

\section{RP-HPLC method development and optimization}

The newly proposed RP-HPLC method was optimized by changing various parameters, such as the mobile phase composition and $\mathrm{pH}$ of the buffer used in the mobile phase. Different mobile phases (Methanol+Phosphate buffer, Methanol+water and Acetonitrile +phosphate buffer) were tested to select a suitable mobile phase for the quantitative determination of caroverine. For selection of mobile phases the criteria employed was to get a prominent peak for caroverine, miscibility of the drug, sensitivity of the method, ease of sample preparation and cost of solvents. Retention time and separation of peak of caroverine were dependent on the $\mathrm{pH}$ of the buffer and the percentage of acetonitrile. Different mobile phases were tried, but satisfactory separation and good symmetrical peak were obtained with the mobile phase consisting of acetonitrile and Buffer solution (30:70) $\mathrm{pH} 4.9$ at run time of $5 \mathrm{~min}$ with retention time of $1.7 \mathrm{~min}$. The column selection and shorter run time represents the cost effectiveness of the proposed method. A typical chromatogram obtained by using the selected mobile phase is shown in Figures 2 and 3.

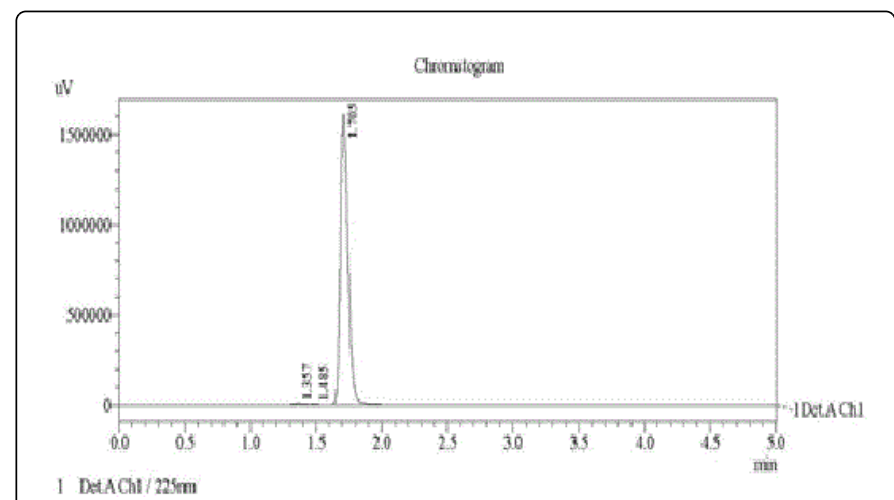

Figure 3: Typical chromatogram of caroverine standard.

\section{Method validation}

The developed method was validated by various parameters which include system suitability, selectivity, specificity, accuracy test, linearity, precision, robustness, ruggedness, sensitivity, limit of detection and quantification, according to US Pharmacopeia and ICH guidelines.

\section{System suitability}

Standard solution was injected on different days to validate the method. Using the system suitability software, theoretical plates and tailing factor for caroverine peak were calculated. Also\% RSD for three replicate injections was calculated. The tailing factor for the caroverine standard peak from the first injection of the standard preparation was 1.424, theoretical plates/meter for caroverine peak from standard solution was 20341.818 and the relative standard deviation for the mean area calculated for caroverine peak from the three replicate injections of standard preparation was $0.21 \%$. The above three system suitability parameters Compliance with the ICH standards.

\section{Linearity}

Linearity was determined in the range $2-150 \mu \mathrm{g} / \mathrm{mL}$. Concentration of caroverine versus peak area was subjected to least square linear regression analysis. A linear regression line was obtained with correlation coefficient $\left(\mathrm{R}^{2}>0.998\right)$. The regression equation for caroverine standard is shown in Table 1 and Figure 4.

\begin{tabular}{|c|c|}
\hline Parameters & Values \\
\hline \multicolumn{2}{|l|}{ System suitability } \\
\hline Retention time (min) & 1.705 \\
\hline Theoretical plates count & 20341.818 \\
\hline Tailing factor & 1.424 \\
\hline Linearity range $(\mu \mathrm{g} / \mathrm{mL})$ & $2-150$ \\
\hline Limit of detection $(\mu \mathrm{g} / \mathrm{mL})$ & 0.068 \\
\hline Limit of quantification $(\mu \mathrm{g} / \mathrm{mL})$ & 0.201 \\
\hline \multicolumn{2}{|l|}{ Regression analysis } \\
\hline Slope & 171274 \\
\hline Intercept & 176062 \\
\hline Correlation coefficient & 0.9989 \\
\hline
\end{tabular}

Table 1: System suitability parameter and regression characteristics for the analysis of caroverine concentration $(\mu \mathrm{g} / \mathrm{mL})$.

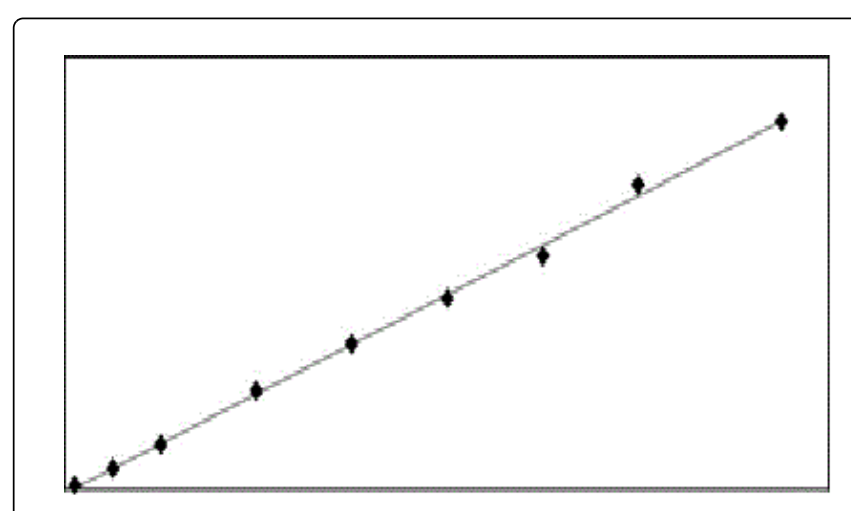

Figure 4: Calibration graph of caroverine. 
Citation: Raza A, Ansari TM (2017) An Innovative Stability Indicating RP-HPLC Assay Method for the Determination of Caroverine in

\section{Specificity and selectivity}

In order to determine the specificity of the method in presence of various excipients and additives, no peak of excipients was found in chromatogram, which proved that the method can be applied successfully to dosage formulation and method demonstrated good resolutions.

\section{Accuracy}

Method accuracy was evaluated as the percentage of recovery of known amounts of caroverine to the pharmaceutical formulation. It is performed at spike concentration that was $40 \%, 80 \%, 100 \%$ and $120 \%$. Each sample was injected five times and result range was 98.9-102.5\%, compiled in Table 2 , high recovery indicated that the method has a high degree of accuracy.

\begin{tabular}{|l|l|l|l|l|}
\hline Label Claim $(\mathbf{m g} / \mathrm{tab})$ & Amount added $(\mathbf{m g})$ & Total amount $(\mathbf{m g})$ & Amount recovered $(\mathbf{m g}) \pm$ RSD $(\%)$ & $\%$ Recovery \\
\hline 20 & 8 & 28 & $27.95 \pm 0.47$ & 99.82 \\
\hline 20 & 16 & 36 & $35.22 \pm 0.87$ & 97.83 \\
\hline 20 & 20 & 40 & $39.67 \pm 0.23$ & 99.17 \\
\hline 20 & 24 & 44 & $43.48 \pm 0.64$ & 98.81 \\
\hline
\end{tabular}

Table 2: Recovery studies ( $n=3)$.

\section{Precision}

Precision of the proposed system and proposed method was determined by repeatability of the injections and testing calculations of percentage assay. Five injections were injected after different intervals and their response was noted from the area and standard deviation was calculated. Different concentrations of caroverine in the linear range were analyzed in the same day (intra-day precision) and two consecutive days (inter-day precision); every sample was injected five times. Both intra and inter day \%RSD values were in the range 0.29 $0.47 \%$ confirming good precision (Table 3). The results were insignificant and indicated no remarkable difference in interday and intraday precision.

\begin{tabular}{|l|l|l|l|l|}
\hline \multicolumn{2}{|l|}{ System precision } & \multicolumn{2}{l|}{ Method precision } \\
\hline Injection no. & Peak area & Sample no. & $\begin{array}{l}\text { Assay (\%) } \\
\text { (Intraday) }\end{array}$ & $\begin{array}{l}\text { Assay (\%) } \\
\text { (Interday) }\end{array}$ \\
\hline 1 & 6880212 & 1 & 99.98 & 100.23 \\
\hline 2 & 6880454 & 2 & 100.24 & 99.67 \\
\hline 3 & 6879765 & 3 & 100.77 & 99.83 \\
\hline 4 & 6834216 & 4 & 101.21 & 100.15 \\
\hline 5 & 6881234 & 5 & 100.73 & 99.56 \\
\hline Mean & 6871176.2 & Mean & 100.59 & 99.89 \\
\hline STD & 20668.25 & STD & 0.4824 & 0.2933 \\
\hline$\%$ RSD & 0.3008 & $\%$ RSD & 0.4796 & 0.2936 \\
\hline
\end{tabular}

Table 3: Data for system and method precision.

\begin{tabular}{|l|l|l|l|l|l|l|}
\hline & Level & Retention time (tR) & Capacity factors (K') & Tailing factor (T) & Resolution (Rs) \\
\hline A: Flow rate (mL/min) & -0.2 & 1.5 & 0.214 & 1.413 & 0.953 \\
\hline 0.8 & 0 & 1.7 & 0.256 & 1.424 & 1.241 \\
\hline 1 & 0.2 & 1.8 & 0.268 & 1.424 & 1.376 \\
\hline S.D. $(\mathrm{n}=5)$ & - & 0.1528 & 0.0284 & 0.0064 & 0.2161 \\
\hline B: Wavelength & & & & \\
\hline
\end{tabular}


Citation: Raza A, Ansari TM (2017) An Innovative Stability Indicating RP-HPLC Assay Method for the Determination of Caroverine in Pharmaceutical Bulk and Tablets. Pharm Anal Acta 8: 540. doi:10.4172/2153-2435.1000540

Page 5 of 7

\begin{tabular}{|c|c|c|c|c|c|}
\hline 220 & -5 & 1.8 & 0.234 & 1.328 & 0.985 \\
\hline 225 & 0 & 1.7 & 0.256 & 1.424 & 1.241 \\
\hline 230 & 5 & 1.5 & 0.261 & 1.487 & 1.326 \\
\hline S.D. $(n=5)$ & - & 0.1528 & 0.0144 & 0.0801 & 0.1775 \\
\hline \multicolumn{6}{|c|}{ C: pH of mobile phase } \\
\hline 4.7 & -0.2 & 1.5 & 0.243 & 1.419 & 1.109 \\
\hline 4.9 & 0 & 1.7 & 0.256 & 1.424 & 1.241 \\
\hline 4.11 & 0.2 & 1.8 & 0.264 & 1.437 & 1.318 \\
\hline S.D. $(n=5)$ & - & 0.1528 & 0.0106 & 0.0093 & 0.1057 \\
\hline \multicolumn{6}{|c|}{ D: Ratio of acetonitrile and buffer } \\
\hline $20 / 80$ & -10 & 1.9 & 0.241 & 1.391 & 1.113 \\
\hline $30 / 70$ & 0 & 1.7 & 0.256 & 1.424 & 1.241 \\
\hline $40 / 60$ & 10 & 1.8 & 0.259 & 1.538 & 1.361 \\
\hline S.D. $(n=5)$ & - & 0.1000 & 0.0096 & 0.0771 & 0.1240 \\
\hline
\end{tabular}

Table 4: Robustness of the proposed analytical method $(n=5)$.

\section{Limit of detection and limit of quantification}

The Limits of Detection (LOD) and Quantification (LOQ) were determined from the calibration curve. The LOD and LOQ were 0.068 $\mu \mathrm{g} / \mathrm{mL}$ and $0.201 \mu \mathrm{g} / \mathrm{mL}$ respectively.

\section{Robustness}

Robustness was accomplished by making minor changes in the percentage of flow rate, wave length, $\mathrm{pH}$ of mobile phase and ratio of acetonitrile and buffer. However, five samples were injected under minor variations of each parameter. When a parameter was changed $\pm 0.2 \%$ (inflow rate), $\pm 0.2 \%$ ( $\mathrm{pH} 3.5$ ), and up to $\pm 5 \%$ wave length from its selected conditions, the change in retention time of $\pm 0.2 \%$ was observed accordingly. The method proved to be quite stable as shown in Table 4.

\section{Ruggedness}

Ruggedness of the newly proposed method was determined in two different labs. First lab was Analytical Laboratory, BioFine pharmaceuticals (Pvt.) Ltd. Multan, Pakistan while other lab was Quality Control department of Hamaz Pharmaceuticals (Pvt.) Ltd. Multan, Pakistan. Two different instruments one was LC 20 and LC 10. Two different columns Shimpack $\mathrm{C}_{18}$ and Supleco HS $\mathrm{C}_{18}$ were used. All parameters were compared the developed method did not show any remarkable difference in calculated results from acceptable limits in precision, but the area under curve of peak was affected with change of wavelength.

\section{Forced degradations and stability indicating property}

Forced degradation studies were carried to prove the specificity of the proposed method. Various chromatograms of samples obtained by treating with acid, base, hydrogen peroxide, light and heat showed prominent separation of peaks for pure caroverine.

\begin{tabular}{|l|l|l|l|l|}
\hline $\begin{array}{l}\text { Mode of } \\
\text { degradation }\end{array}$ & Condition & Peak area & $\begin{array}{l}\text { Assay } \\
\mathbf{1} \% \\
\text { claim })\end{array}$ & \% Degradation \\
\hline Control & No treatment & 6880212 & 100.56 & - \\
\hline Acid degradation5N & $\begin{array}{l}5 \mathrm{~mL} / 70^{\circ} \mathrm{C} / 30 \\
\mathrm{~min}\end{array}$ & 7009825 & 101.88 & -1.32 \\
\hline $\mathrm{HCl}$ & - & - & - & - \\
\hline $\begin{array}{l}\text { Alkali } \\
\text { degradation } 0.1 \mathrm{~N}\end{array}$ & $\begin{array}{l}5 \mathrm{~mL} / 70^{\circ} \mathrm{C} / 30 \\
\mathrm{~min}\end{array}$ & -7149491 & 103.91 & -3.35 \\
\hline $\mathrm{NaOH}$ & $\begin{array}{l}5 \mathrm{~mL} / 70^{\circ} \mathrm{C} / 30 \\
\mathrm{~min}\end{array}$ & 4781948 & 69.5 & 31.06 \\
\hline $\begin{array}{l}\text { Peroxide } \\
\text { degradation } 3 \%\end{array}$ & - & - & - & - \\
\hline w/v $\mathrm{H}_{2} \mathrm{O}_{2}$ & $105^{\circ} \mathrm{C} / 168 \mathrm{~h}$ & 6684832 & 97.16 & 3.4 \\
\hline $\begin{array}{l}\text { Thermal } \\
\text { degradation }\end{array}$ & $200 \mathrm{~W} \mathrm{h/ \textrm {m } ^ { 2 }}$ & 7125992 & 103.57 & -3.01 \\
\hline $\begin{array}{l}\text { Photolytic } \\
\text { degradation }\end{array}$ & & - & - \\
\hline
\end{tabular}

Table 5: Results of forced degradation study.

The chromatogram of no stress treatment sample (as control) showed no additional peak (Figure 5). The retention time of standard and sample were $1.705 \mathrm{~min}$. The chromatogram of acid degraded sample showed no additional peaks (Figure 6). The chromatogram of alkali degraded sample showed no additional peaks (Figure 7). The chromatogram of thermal degraded sample showed no additional 
Citation: Raza A, Ansari TM (2017) An Innovative Stability Indicating RP-HPLC Assay Method for the Determination of Caroverine in

peaks (Figure 8). The chromatogram of photo degraded sample showed one major peak at retention time of $1.712 \mathrm{~min}$ (Figure 9).

However the chromatogram obtained by treatment of peroxide degradation show one minor peak at 1.237 min and major peak 1.479 min (Figure 10). A prominent degradation is observed under these conditions that is almost $31.06 \%$.

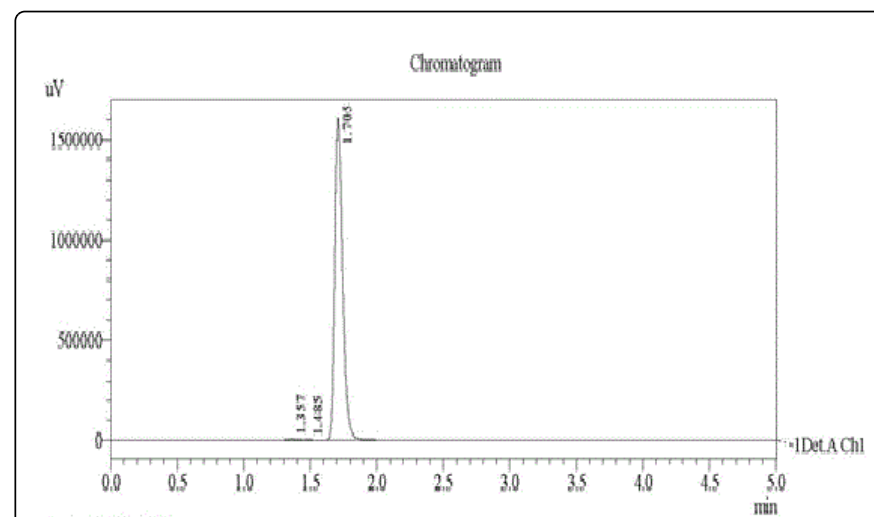

1 DetAChi $/ 223 \mathrm{~mm}$

Figure 5: Typical chromatogram of caroverine sample.

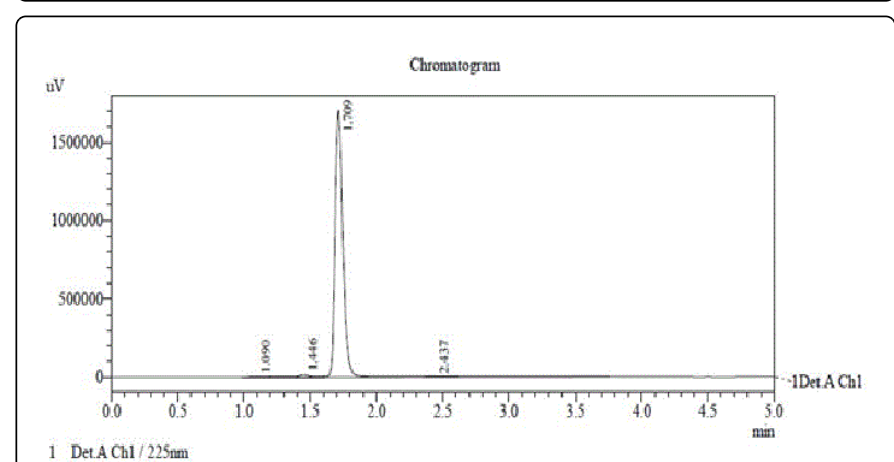

Figure 6: Acid degradation chromatogram.

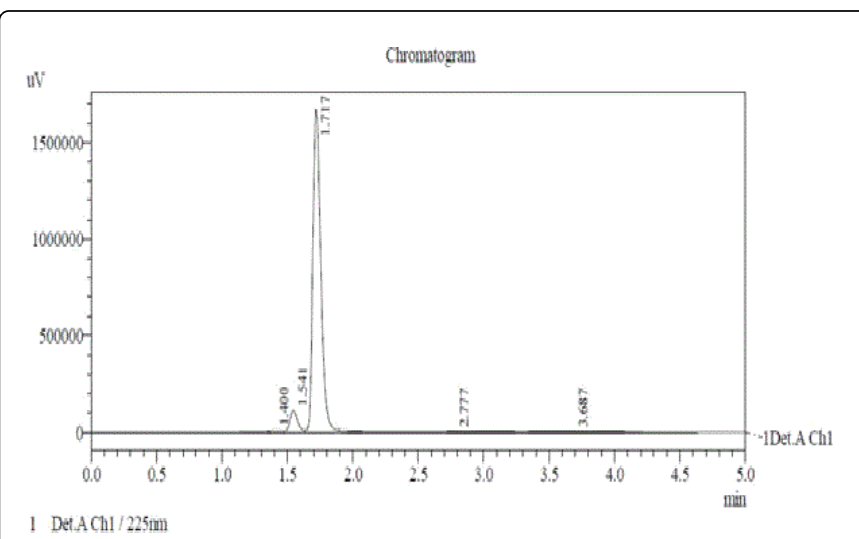

Figure 7: Alkali degradation chromatogram.

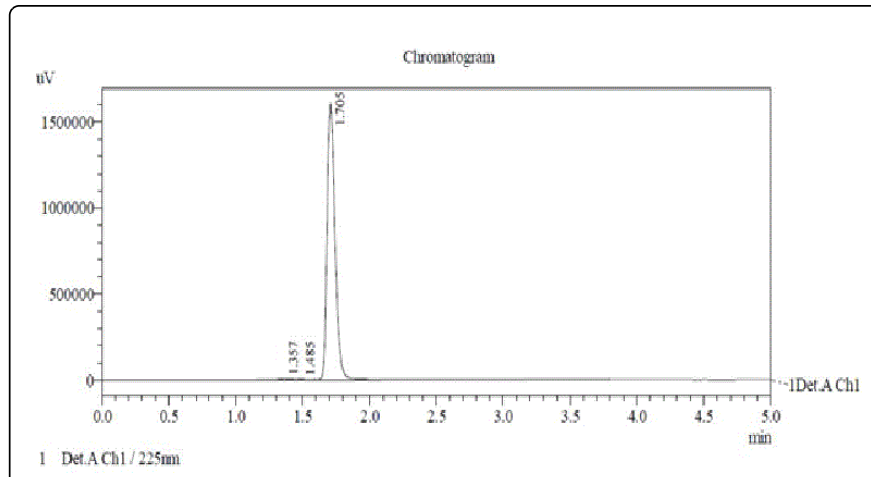

Figure 8: Thermal degradation chromatogram.

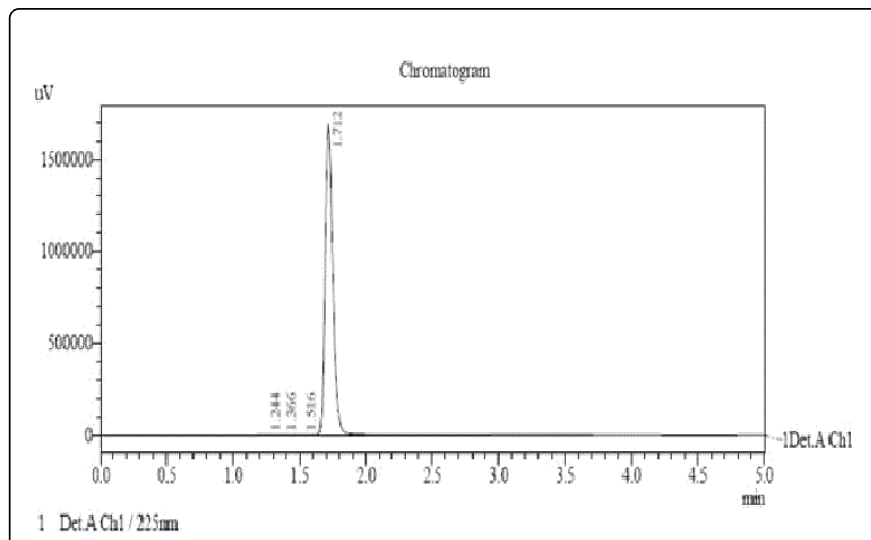

Figure 9: Light degradation chromatogram.

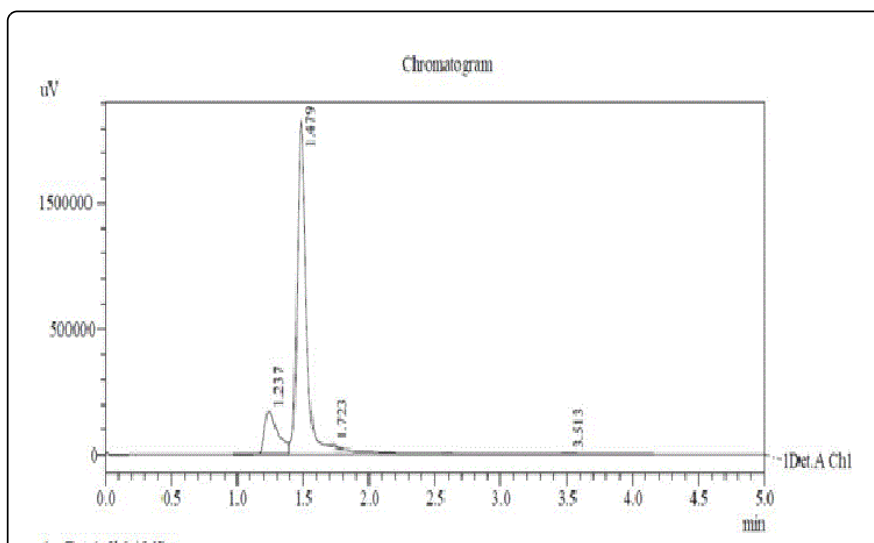

1 DetAchl $/ 265 \mathrm{~mm}$

Figure 10: Peroxide degradation chromatogram.

\section{Solution stability and mobile phase stability}

To study the stability of sample solution and mobile phase we stored them at ambient temperature for $24 \mathrm{~h}$. caroverine sample solution was re-analyzed after 12 and $24 \mathrm{~h}$ by using the same mobile phase. The assay result was calculated and compared with fresh sample. Sample solution did not show any considerable change in assay value when stored at ambient temperature up to $24 \mathrm{~h}$, which are presented in Table 
Citation: Raza A, Ansari TM (2017) An Innovative Stability Indicating RP-HPLC Assay Method for the Determination of Caroverine in Pharmaceutical Bulk and Tablets. Pharm Anal Acta 8: 540. doi:10.4172/2153-2435.1000540

Page 7 of 7

5 and 6 . The results from solution stability experiments confirmed that sample solution and mobile phase was stable for up to $24 \mathrm{~h}$ during assay determination.

\begin{tabular}{|l|l|l|l|}
\hline & Initial & After $\mathbf{1 2} \mathbf{h}$ & After $\mathbf{2 4} \mathbf{h}$ \\
\cline { 2 - 4 } & 99.98 & 100.12 & 100.14 \\
\cline { 2 - 4 } \% Assay & 100.25 & 99.78 & 99.75 \\
\hline
\end{tabular}

Table 6: Solution and mobile phase stability results.

\section{Conclusion}

The present work is novel it its sense that up till now not a single analytical method is reported in the literature for quantitative determination of caroverine in pharmaceutical raw and dosage form. The present RP-HPLC method for the determination of assay of caroverine in pharmaceutical raw and tablet dosage form is simple, rapid, economical, precise and accurate. The method has been validated and satisfactory results were observed for all the tested validation parameters. Hence, the newly developed method can be easily applied for the determining of caroverine in pharmaceutical quality control laboratories. Moreover, the lower solvent consumption along with the short analytical run time of 5.0 min leads to cost effective chromatographic method.

\section{References}

1. Davison M (2011) Pharmaceutical Anti-Counterfeiting: Combating the Real Danger from Fake Drugs. John Wiley \& Sons, Inc.

2. Udilova N, Kozlov AV, Bieberschulte W, Frei K, Ehrenberger K, et al. (2003) Bio Pharmaco 65: 59-65.

3. Nohl H, Bieberschulte W, Dietrich B, Udilova N, Kozlov AV (2003) Caroverine, a multifunctional drug with antioxidant functions. Bio Factors 19: 79-85.

4. (1996) Q2(R1) Validation of Analytical Procedures: Text and Methodology, Note for guidance on validation of analytical procedures: methodology. 